\title{
AN ESTIMATION OF THE ROTATION AGE USING AUTOREGRESSIVE PRICE MODEL AND TRUNK ANALYSIS DATA: RESULTS FOR PINUS BRUTIA TEN
}

\author{
NAMDARI, S. - ADELI, K. ${ }^{*}$ - SOOSANI, J. - OSTAKH, E. \\ Faculty of Agricultural and Natural Resource, Lorestan University \\ Khoramabad, Iran \\ *Corresponding author \\ e-mail:adeli.k@lu.ac.ir \\ (phone:+98-916-367-5283; fax: +98-663-340-0191) \\ (Received 15 ${ }^{\text {th }}$ Jun 2017; accepted 6 ${ }^{\text {th }}$ Dec 2017)
}

\begin{abstract}
The present study was conducted in southwestern Iran and it aimed to determine the optimal rotation age of Turkish pine (Pinus brutia Ten) at which the marginal revenue equaled to the marginal cost. The volume growth, stumpage price, setup cost and interest rate were considered as essential factors for calculating the optimal rotation age. The data of volume growth were extracted through Trunk Analysis Method and stumpage price of Pinus brutia was estimated through autoregressive model. The results showed that the optimal harvest age of Pinus brutia occured in the age range of 18 to 23 years when the land's expected value maximizes. It is noteworthy that cultivation of the stated species was found to be economically justifiable in this area.
\end{abstract}

Keywods: Pinus brutia, Turkish pine, stumpage price, optimal rotation age, Faustmann model

\section{Introduction}

Forest rotation refers to the period of time between stand establishment and harvest which is applied for forests with even-aged management. On the other hand, rotation age refers to the age when stand must be harvested or clear-cut. The calculation of this period is necessary to achieve the economic and sustainability goals of the harvester (Posavec et al., 2011). The most commonly used criteria to maximize productivity of forest stands are: (1) maximum single-rotation physical yield (2) maximum singlerotation annual yield (3) maximum internal rate of return (4) maximum annual net revenues (5) maximum discounted net revenues from an infinite series of rotation (Newman, 1988). The idea of optimal economic age was first introduced by Faustmann (1849) and is extensively used in evaluating the financial maturity of a forest stand. Regarding this criterion, foresters and natural resources managers have traditionally assumed that forestlands will be under timber production for ever, under the condition that the harvested stands are rapidly replaced by other ones. Therefore, Faustmann criterion is called discounted benefits to infinity (DBI) or land's expected value (LEV). In this model, optimal solution occurs when the land's expected value is in its maximum level and marginal revenue of production equals marginal cost of input (Chang, 1984).

Since 1957 optimal rotation age has been studied by various researchers using the models with different levels of complexity (Gaffney, 1957; Näslund, 1969; Anderson, 1976; Reed, 1986; Engindeniz, 2003; Petit and Montagnini, 2004; Posavec et al., 2011; Pourmajidian et al., 2013; Brazee and Dwivedi, 2015). Some of these studies have used Faustmann criterion (Zhang, 2001; Brazee and Dwivedi, 2015) and other studies have applied other criteria for calculating the optimal rotation age (Engindeniz, 2003; Petit 
and Montagnini, 2004). Chang (1984) investigated the relationship among the Land's Expected Value model, Net Present Value model, Forest Renting model and Traditional Biologic model and showed that the three latter models are special cases of the Land's Expected Value model. Land's Expected Value model is the most accurate model for calculating the optimal rotation age by taking into accounts the opportunity cost of stand as well as opportunity cost of land (Newman, 1988; Pearse, 1967). To determine the optimal economical rotation in even-aged forests, a combination of information including forest growth, stumpage price, cost and interest rate is required (Mohammadi Limaei et al., 2013) and it is usually assumed that: 1) The forest growth and stumpage price are constant. 2) Utilization costs are not undertaken by the owner and trees are sold as stand stock. 3) The risk of pests and tree uprooting is very low and it is ignored. 4) Tax is not paid to government. 5) Thinning is not performed (Amacher et al., 2009).

Since Iran is not rich in terms of native coniferous species, the government has to import paper pulp and long-fibers of coniferous species for the pulp and paper industries demand. These imports remarkably increase the currency outflow. Hence, it must be attempted to develop plantations of fast-growing species or wood farming in various parts of the country (Nouri, 1999; Arian et al., 2017). In the present study, Pinus brutia was selected because of its good physical and mechanical properties in commercial pulp production (Üner et al., 2011; Fakhryan Roghani, 2015). The aim of this research is to determine whether this species is economically justifiable or not, and to calculate the maximum net present value in an infinite series or estimate the optimal rotation age.

\section{Materials and Methods}

This study was carried out in a 33-year old area under Pinus brutia plantation in western Iran. The study area is located at $48^{\circ} 20 \mathrm{E}$ and $33^{\circ} 30 \mathrm{~N}$ and $1270 \mathrm{~m}$ above sea level. The area is characterized by Mediterranean climate with mean annual temperature and mean annual rainfall of $17^{\circ} \mathrm{C}$ and $552 \mathrm{~mm}$ respectively. This plantation was established in 1978 with a planting distance of $2 \times 3 \mathrm{~m}$ and is managed by Khorramabad Park and Green Space Organization. As mentioned above, growth value, stumpage price, interest rate and setup costs are essential factors to calculate the optimal age by Faustmann model (Mohammadi Limaei et al., 2013). These parameters are calculated as follows:

\section{Growth of Pinus brutia}

Stand measurement method and trunk analysis method are two prevailing approaches to measure the growth characteristics of a tree. In the second method, which is more accurate to estimate growth parameters, trees are cut down and growth component is calculated according to trunk analysis and annual rings count (Zobeiry, 1994).

In this study, the data of growth was extracted from a previous study conducted by Ostakh (2013) to evaluate the effect of climatic factors on the growth rings of Pinus brutia. They selected 31 trees using selective method and cut them down. Then five disks were prepared from various heights of trunk. After preparation of disks, the width of annual rings was measured with an accuracy of $0.001 \mathrm{~mm}$ for various years. Finally they have estimated the growth components including current annual increment (CAI), mean increment (MI) and volume stock in different ages of considered stand which will be used in the present study (Table 1). Figs. 1.a and $1 . b$ show the amount of volume stock $\left(\mathrm{m}^{3} / \mathrm{ha}\right)$ in various ages and the relationship between CAI and volume stock $\left(\mathrm{m}^{3} / \mathrm{ha}\right)$. 


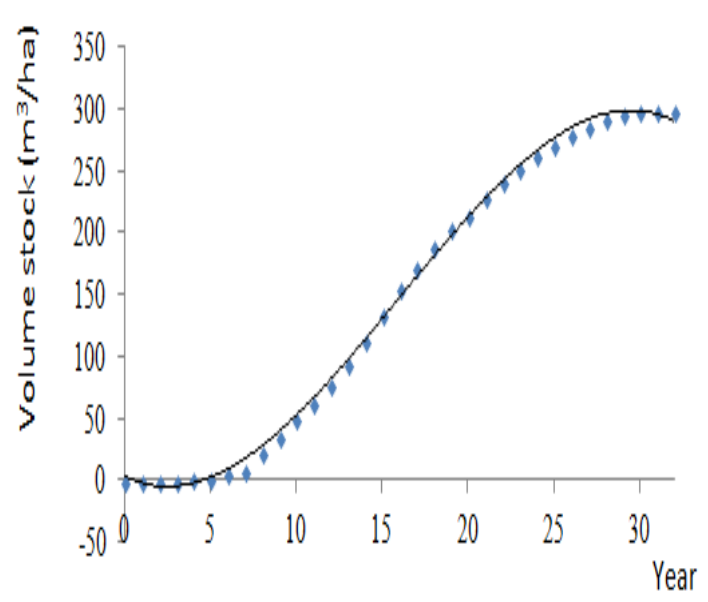

(a)

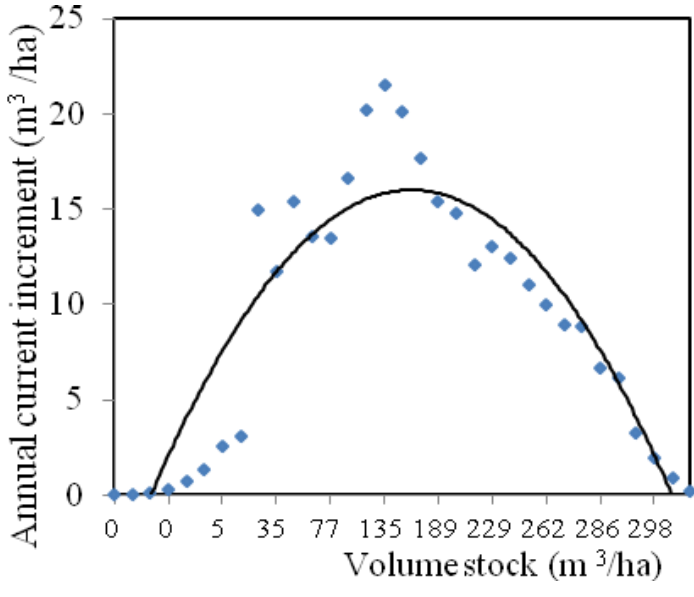

(b)

Figure 1. a: Volume stock per ha in various ages of the Pinus brutia stand, $b$ : Relationship between CAI and volume stock per ha of the Pinus brutia stand

Table 1. Annual increment, mean increment, volume

\begin{tabular}{|c|c|c|c|}
\hline Age & $\begin{array}{c}\text { Current Annual Increment } \\
\qquad\left(\mathrm{m}^{3} / \mathrm{ha}\right)\end{array}$ & $\begin{array}{l}\text { Mean Increment } \\
\left(\mathbf{m}^{3} / \mathbf{h a}\right)\end{array}$ & $\begin{array}{l}\text { Volume } \\
\left(\mathbf{m}^{3} / \mathbf{h a}\right)\end{array}$ \\
\hline 1 & 0.0119 & 0.0119 & 0.0119 \\
\hline 2 & 0.0357 & 0.0238 & 0.0477 \\
\hline 3 & 0.0903 & 0.0460 & 0.1380 \\
\hline 4 & 0.2544 & 0.0981 & 0.3925 \\
\hline 5 & 0.7468 & 0.2278 & 1.1394 \\
\hline 6 & 1.3592 & 0.4164 & 2.4986 \\
\hline 7 & 2.5155 & 0.7163 & 5.0141 \\
\hline 8 & 3.0516 & 1.0067 & 8.0537 \\
\hline 9 & 14.922 & 2.5542 & 22.987 \\
\hline 10 & 11.750 & 3.4737 & 34.737 \\
\hline 11 & 15.355 & 4.5539 & 50.093 \\
\hline 12 & 13.557 & 5.3042 & 63.651 \\
\hline 13 & 13.508 & 5.9353 & 77.159 \\
\hline 14 & 16.586 & 6.6961 & 93.746 \\
\hline 15 & 20.214 & 7.5972 & 113.95 \\
\hline 16 & 21.531 & 8.4681 & 135.49 \\
\hline 17 & 20.066 & 9.1504 & 155.55 \\
\hline 18 & 17.658 & 9.6230 & 173.21 \\
\hline 19 & 15.435 & 9.9289 & 188.65 \\
\hline 20 & 14.813 & 10.173 & 203.46 \\
\hline 21 & 12.088 & 10.264 & 215.55 \\
\hline 22 & 12.996 & 10.388 & 228.54 \\
\hline 23 & 12.396 & 10.475 & 240.94 \\
\hline 24 & 11.068 & 10.500 & 252.01 \\
\hline 25 & 9.9699 & 10.479 & 261.94 \\
\hline 26 & 8.9584 & 10.420 & 270.94 \\
\hline 27 & 8.8442 & 10.362 & 279.78 \\
\hline 28 & 6.7028 & 10.231 & 286.48 \\
\hline 29 & 6.0968 & 10.089 & 292.58 \\
\hline 30 & 3.2545 & 9.8613 & 295.84 \\
\hline 31 & 1.9349 & 9.6056 & 297.77 \\
\hline 32 & 0.8587 & 9.3323 & 298.63 \\
\hline 33 & 0.1744 & 9.0548 & 298.80 \\
\hline
\end{tabular}

APPLIED ECOLOGY AND ENVIRONMENTAL RESEARCH 16(1):281-290. http://www.aloki.hu • ISSN 15891623 (Print) • ISSN 17850037 (Online) DOI: http://dx.doi.org/10.15666/aeer/1601_281290 (C) 2018, ALÖKI Kft., Budapest, Hungary 


\section{Estimation of the stumpage price equation of Pinus brutia}

There are two approaches to estimate the wood price among economists. According to the first approach, the price follows a stationary autoregressive model, that is to say, the changes which occur in a period will have no significant effect on the price of the next period and the best method for forecasting the price is to calculate the average of the previous prices. This way, prices can be estimated using the following formula: $P_{t+1}=\alpha+\beta P_{t}$, where $0<\beta<1$.

In the second approach, the price is non-stationary and does not follow the aforesaid stationary condition. In this situation, the price in the next year or period completely depends on the price in previous year or period. The price in this case, can be evaluated as $P_{t+1}=\beta P_{t}, \beta=1$ (Lindahl and Plantinga, 1997; Dickey and Fuller, 1981; Mohammadi Limaei, 2006).

After testing the price data, it was found that due to the stationary type of data, stationary autoregressive model was used for estimating the parameters. It should be noted that the data of the period 1993-2012 was collected from the Natural Resources Organization and interview carpenters. Then it was adjusted to Consumer Price Index (CPI) of Iran for the base year of 2011 (Fig. 2) (Central Bank of Iran, 2014).

$$
P_{r}=\frac{P_{t}}{y_{t}} \times 100
$$

Where Pr is the real price, $\mathrm{Pt}$ is the price in year $\mathrm{t}$ and $\mathrm{yt}$ is the price index in year $\mathrm{t}$ and 100 is the value of price index in basic year (Branson, 1989).

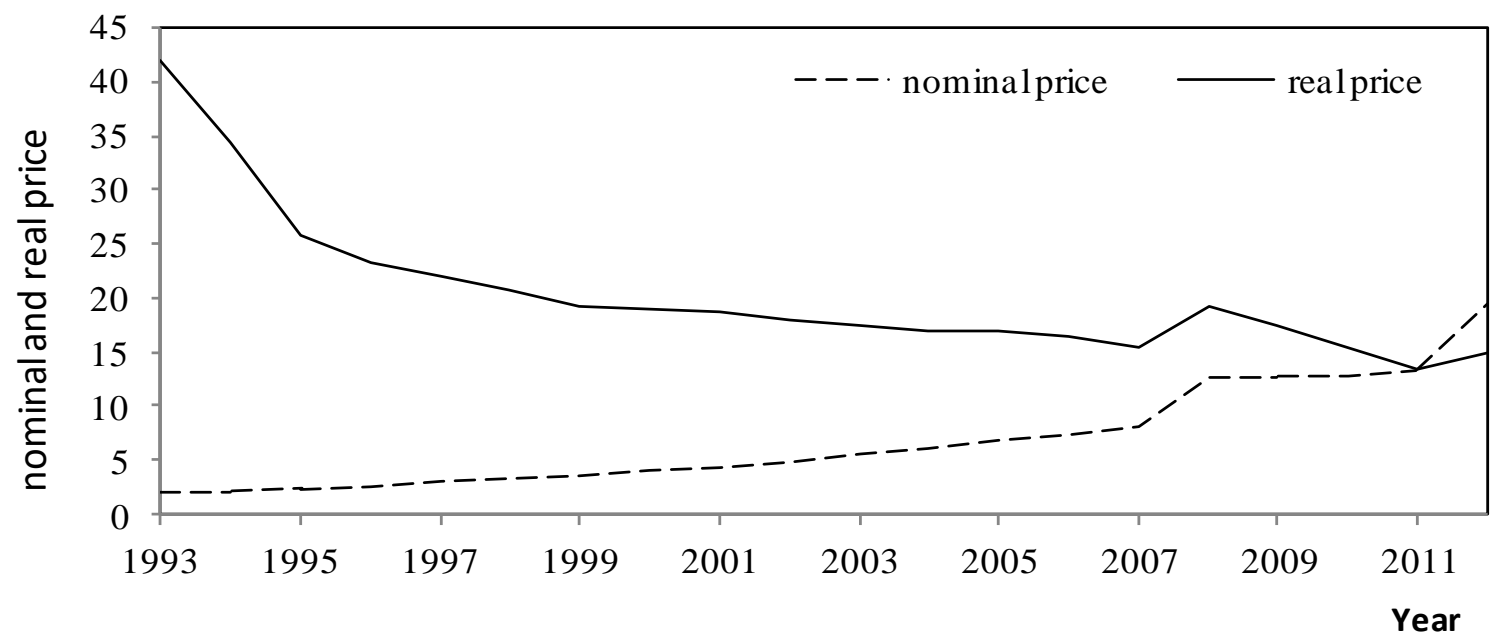

Figure 2. Nominal (non-adjusted) and real (adjusted) prices of Pinus brutia in period of 19932012

Then, a regression model was used for estimating the price of each $\mathrm{m}^{3}$ of the Pinus brutia Ten (Lindahl and Plantinga, 1997; Mohammadi limaei and Lohmander, 2007).

$$
p_{t+1}=\alpha+\beta p_{t}+\varepsilon_{t}
$$


Here, it is assumed that $\varepsilon_{\mathrm{t}}$ is a sequence of errors with normal distribution, mean of zero and zero autocorrelation. $\mathrm{P}_{\mathrm{t}+1}$ is the price in the year $\mathrm{t}+1$ and $\mathrm{P}_{\mathrm{t}}$ is the price in year t. Expected mean stumpage price is calculated as follows:

$$
P_{e q}=\frac{\alpha}{1-\beta}
$$

\section{Faustmann expected value}

Since Faustmann formula includes economic parameters in estimation of rotation age, it was chosen to be applied in this study. In this method it is attempted to select the length of rotation so that the land's expected value is maximized.

Details of Faustmann model, which assumes that a land will be under forest cultivation forever, is explained as follows: net present value resulting from harvesting after the first rotation is shown in Eq. 4, where $\mathrm{T}$ is the decision variable or rotation period, $p$ is the price per $\mathrm{m}^{3}$ of stumpage, $\mathrm{f}(\mathrm{T})$ is the standing volume stock in time $\mathrm{T}, \mathrm{r}$ is the interest rate, $\mathrm{c}$ is set up cost in time 0 , and e is Nepper number. Here, $\mathrm{e}^{-\mathrm{rT}}$ is referred to as discount rate which is continuous time approximation of $\frac{1}{(1+r)^{\mathrm{T}}}$.

$$
\mathrm{pf}(\mathrm{T}) \mathrm{e}^{-\mathrm{rT}}-\mathrm{c}
$$

Net present value of an infinite series with similar rotations is stated as follows:

$$
p f(T) e^{-r T}-c+\left[p f(T) e^{-r T}-c\right] e^{-r T}+\left[p f(T) e^{-r T}-c\right] e^{-2 r T}+\left[p f(T) e^{-r T}-c\right] e^{-3 r T}+
$$

By factoring $\left(\mathrm{pf}(\mathrm{T}) \mathrm{e}^{-\mathrm{rT}}-\mathrm{c}\right)$, an infinite converging series can be obtained:

$$
\left(1+e^{-r T}+e^{-2 r T}+e^{-3 r T}+\cdots\right)\left(p f(T) e^{-r T}-c\right)
$$

By summing the converging function to infinite which is obtained by multiplying the first term by $\frac{1}{1-q}$ ( $q$ is common ratio of progression as $e^{-n r}$ ) and by substituting the sum of converging function in the series shown in number 6 :

$$
v=p f(T) \mathrm{e}^{-r \mathrm{~T}}-c\left(1-e^{-r t}\right)^{-1}
$$

Here, numerator of the fraction shows the present value of a rotation and denominator indicates the discount factor of future rotations to infinite. This equation is called Faustmann equation, land's expected value (LEV), or soil's expected value (SEV). To obtain the age at which net present value of forest is maximized, the derivation of the above term is set equal to zero.

$$
\mathrm{v}_{\mathrm{T}}=\mathrm{pf}^{\prime}(\mathrm{T})-\mathrm{rpf}(\mathrm{T})-\mathrm{rv}=0
$$

And finally, optimality condition of the Faustmann model is as follows:

$$
\mathrm{pf}^{\prime}(\mathrm{T})=\operatorname{rpf}(\mathrm{T})+\mathrm{rv}
$$


According to the optimality condition of the Faustmann model, age is increased to a point that marginal revenue equals marginal cost. Here, $\mathrm{f}^{\prime}(\mathrm{T})$ is the current increment of the year $\mathrm{T}$.

\section{Results}

\section{Growth of Pinus brutia}

According to Table 1, maximum annual current increment of the species is 21.531 $\mathrm{m}^{3}$ per ha and volume stock in age 33 is $298.80 \mathrm{~m}^{3}$ per ha. Current Annual Increment (CAI) and Mean Annual Increment (MAI) will be equal at the age of 24 which is called biologically optimal rotation age.

\section{Stumpage price model for Pinus brutia}

As explained in Fig. 2, the change in trend of nominal price is in line with real price, however, real price increases with a higher slope in comparison to nominal price. It means that a major portion of increase in the price of Pinus brutia in the study period has occured as a result of inflation. Assessing the details of the nature and reasons of inflation in various years which may be due to increase in demand, structural inflation, inflation expectations and inflation as a result of expenses pressure is out of the limits of this work.

After adjusting the data for the base year (Fig. 2) autoregressive analysis was used to estimate the expected prices. According to the results and the t-value with a confidence level of $95 \%$, it was found that there was a significant correlation between parameters $\mathrm{P}_{\mathrm{t}+1}$ and $\mathrm{P}_{\mathrm{t}}$. Moreover, the results of this analysis revealed that $\beta$ varied between 0 and 1 , and stationary condition was observed (Table 2).

Table 2. estimated parameters using autoregressive analysis

\begin{tabular}{c|c|c|c|c|c}
\hline & $\alpha$ & $\beta$ & $R$ & $R^{2}$ & $\begin{array}{c}\text { Standard } \\
\text { deviation of } \varepsilon\end{array}$ \\
\hline $\begin{array}{c}\text { Parameter } \\
\text { value }\end{array}$ & 186379.95 & 0.655 & 0.957 & 0.916 & 46598.47804 \\
$\begin{array}{c}\text { Standard } \\
\text { deviation }\end{array}$ & 34132.095 & 0.048 & & & \\
\begin{tabular}{c} 
T-statistics \\
\hline
\end{tabular} & 5.461 & 13.644 & & & \\
\hline
\end{tabular}

Price predicting equation for Pinus brutia was calculated through the estimated parameters obtained from the regression analysis, and substituting the value of parameters $\alpha$ and $\beta$ in Eq. 2, as follows:

$$
\mathrm{P}_{\mathrm{t}+1}=186379.95+0.655 \mathrm{P}_{\mathrm{t}}
$$

And using Eq. 3, expected mean stumpage price of Pinus brutia was obtained to be 540229 RLs (16\$) per $1 \mathrm{~m}^{3}$.

$$
P_{\text {eq }}=\frac{186379.95}{1-0.655}=540229
$$




\section{Economic rotation age of Pinus brutia}

As mentioned above, four main components are needed for calculating the LEV. The Growth data was extracted from the trunk analysis table provided by Ostakh (2013), and the expected price mean was predicted by autoregressive model. Interest rate and set up cost were considered 2\%-8\% and 500000-1000000 RLS (15.26-30.52 \$), respectively. After substituting the mentioned components in Faustmann formula, optimal rotation age was calculated, where land's expected value was maximized or marginal revenue of production equaled marginal cost of input. As seen in Table 3 optimal rotation age fluctuates from 18 to 23 years owing to different interest rates and various setup costs. It can be said by increasing interest rate, optimal rotation age will decrease and by reducing the setup cost, optimal rotation age will increase.

Table 3. The Optimal rotation age considering various interest rates and setup costs

\begin{tabular}{c|c|c|c|c|c|c|c}
\hline $\begin{array}{l}\text { Interest rate } \\
\text { setup cost }\end{array}$ & $\mathbf{2 \%}$ & $\mathbf{3 \%}$ & $\mathbf{4 \%}$ & $\mathbf{5 \%}$ & $\mathbf{6 \%}$ & $\mathbf{7 \%}$ & $\mathbf{8 \%}$ \\
\hline 500000 & 22 & 20 & 20 & 19 & 19 & 18 & 18 \\
600000 & 22 & 20 & 20 & 19 & 19 & 18 & 18 \\
700000 & 23 & 20 & 20 & 20 & 19 & 18 & 18 \\
800000 & 23 & 20 & 20 & 20 & 19 & 18 & 18 \\
900000 & 23 & 20 & 20 & 20 & 19 & 18 & 18 \\
100000 & 23 & 22 & 20 & 20 & 19 & 18 & 18 \\
\hline
\end{tabular}

\section{Discussion and Conclusion}

One of the most important goals of planting the coniferous species in Iran is rehabilitation and restoration of degraded forests as pioneer species during succession stages (Sardabi, 1998). Although most of Pinus brutia plantations are planted for aesthetic and protective purposes, research has revealed that they are suitable in terms of growth efficiency for wood production (Fattahi, 1994; Radaei, 2002).

As mentioned above, in this study, the growth data were extracted from the trunk analysis table which was calculated by Ostakh (2013), Since the trunk analysis method has higher accuracy in estimating the stand volume in comparison to stand measurement method (Zobeiry, 1994), in the present study, the required growth data for calculating the optimal rotation age was extracted through trunk analysis method for the first time. While in most of the previous studies focusing on the rotation age, stand measurement method was used for gathering the growth data (Mohamadi Limaie et al., 2013; Ranjbar et al., 2009).

As shown in Table 2, studied plantation with CAI, MAI and stock volume equal $20.066\left(\mathrm{~m}^{3} / \mathrm{ha}\right), 9.1504\left(\mathrm{~m}^{3} / \mathrm{ha}\right)$ and $155.55\left(\mathrm{~m}^{3} / \mathrm{ha}\right)$, respectively at the age of 17 , and it is of relatively proper efficiency for wood production. Therefore, the studied region can be considered as a good site for plantation according to the provided product table by Usta (1991).

It should be noted that this stand has been affected by drought in the middle of its age (Ostakh, 2013) which has affected the process of growth stand and has reduced volume growth in the region under study in comparison to other regions of Iran with similar ecological conditions (Yousefi et al., 2013; Sadegh Zadeh Hallaj and Rostaghi, 2011). 
CAI and MAI became equal after 24 years and it can be inferred that MAI reaches its peak at this point (Table 2). This peak point varies owing to different site conditions (Engindeniz, 2003). The optimal rotation age which was calculated through the stated method relies entirely on biological information.

Faustman model is the best method for determining the optimal rotation age due to considering the opportunity cost of land as well as opportunity cost of stand (Newman, 1988; Pearse, 1967). It should be noted that the optimal rotation age, calculated by Faustmann model, is shorter than the optimal biological rotation age because of considering economic parameter. Various factors contribute to the optimal rotation age including site quality (Marutani, 2010), carbon subsidiary and tax (Kooten et al., 1995), fire risk and discount rate (Pasalodos, 2010), establishment costs and interest rate (Mohamadi Limaei et al., 2011; Alvarez and Koskela, 2003), non-monetary benefits of forest (Hartman, 1976) and these factors change extensively in various conditions.

According to Petit and Montagnini (2004), determination of optimal rotation age and estimation of the amount of wood produced at that age is necessary for forest sustainability and management; therefore, this issue was taken into consideration. In recent years, farmers have used poplar species around their farms and most of the research in this area has been conducted to determine the optimal rotation age of this species. Coniferous species are planted and utilized by farmers to a lower degree, while a large volume of paper pulp of these species is imported from other countries (Adeli et al., 2012).

According to the studies carried out in Iran, Pinus brutia is a suitable species for foresting and restoring of forests in Iran owing to its ecologic conditions which are similar to Pinus brutia's native country; therefore, this paper investigated this species in terms of economic conditions. According to the results, the age of economic rotation in Khorramabad was found to be between 18-23 years.

It must be noted that the studied region is classified as a good site because this species has a relatively suitable growth rate and short optimal rotation age for plantation in this area. It is proposed that other parts of Iran especially those with suitable conditions be investigated in order to avoid a huge currency outflow which occurs due to importing the paper pulp of coniferous species.

Owing to the limitations in wood extraction from Iran's forests, it seems necessary to plant fast-growing species in order to solve the problem of wood shortage.

In this study, factors contributing to determination of the optimal age using Faustmann model such as price and increment were considered constant. As a future line of research, it is recommended to compute the optimal age by considering stochastic states.

\section{REFERENCES}

[1] Adeli, K., Yachkaschi, A., Mohammadi Limaei, S., Fallah, A. (2012): Condition of Timber Production in Iran and the Expected Production Rate in the Next Decade. Journal of Sustainable Development 5(1): 144-154.

[2] Alvarez, L. H. R., Koskela, E. (2003): On Forest Rotation under Interest Rate Variability. - International Tax and Public Finance 10: 489-503.

[3] Amacher, G. S., Ollikainen, M., Koskela, E. (2009): Economics of Forest Resources. The MIT Press, Cambridge, MA, 397 p. 
[4] Anderson, F. J. (1976): Control theory and optimum timber rotation. - Forest Science 22: 242-246.

[5] Arian, A., Faezipour, M., Azizi, M., Vlosky, R., Leavengood, S. (2017): Evaluation of challenges of wood imports to Iran using Fuzzy Delphi Analytical Hierarchy Process. Iranian Journal of Wood and Paper Industries, 8(2): 159-169.

[6] Branson, W. H. (1989): Macroeconomic Theory and Policy. - Harper \& Row, Third Edition.

[7] Brazee, R. J., Dwivedi, P. (2015): Optimal Forest Rotation with Multiple Product Classes. - Forest science 61(3): 458-465.

[8] Central Bank of Iran. (2014): www.cbi.ir

[9] Chang, S. J. (1984): Determination of the optimal rotation age: a theoretical analysis. Forest Ecology and Management 8: 137-147.

[10] Dickey, D. A., Fuller, W. A. (1981): Likelihood ratio statistics for Autoregressive time series with a unit root. - Econometrica 49(4):1057-1072.

[11] Engindeniz, S. (2003): Determination of Economical financial rotation lengths of hybrid Poplar plantations; The case of Turkey. - Pakistan Journal of biological Sciences 6(4): 325-330.

[12] Fakhryan Roghani, A. (2015): Investigation on the possibility of Manufacturing the Kraft pulp from Criptomeria wood. - Iranian Journal of Wood and Paper Industries 6(1): 145157.

[13] Fattahi, M. (1994): Evaluation of exotic softwoods compatible in Kurdistan. - The Research Institute of Forests and Rangelands 109, 54 p.

[14] Faustmann, M. (1849): Berechnung des Wertes, welchen Waldboden, sowie noch haubare Holzbestände für die Waldwirtschaft besitzen. - Allgemeine Forst und Jagdzeitung 12: 441-455.

[15] Gaffney, M. M. (1957): Concept of financial maturity of timber and other assets. Agricultural Economics. Information. Ser.62, Department of Agricultural Economy, North Carolina State College, Raleigh, NC, 105 PP.

[16] Hartman, R. (1976): The harvesting decision when the standing forest has value. Economic Inquiry 14(1): 52-58.

[17] Kooten, G, Binkley, C., Delcourt, G. (1995): Effect of carbon taxes and subsidies on optimal forest rotation age and supply of carbon services. - American Journal of Agricultural Economics 77(2): 365-374.

[18] Lindahl, J. B., Plantinga, A. J. (1997): Time-Series Analysis of Maine Stumpage Prices. Department of Resource Economics and Policy, University of Maine, Orono, ME 04469.

[19] Marutani, T. (2010): The effect of site quality on economically optimal stand management. - Journal of Forest Economics 16: 35-46.

[20] Mohammadi Limaei, S. (2006): Economically optimal values and decisions in Iranian forest management. - Doctoral thesis. Dept. of Forest Economics, Swedish University of Agricultural Sciences (SLU). Acta Universitatis Agriculturae Sueciae 91, 21 p.

[21] Mohammadi Limaei, S., Bahramabadi, Z., Rostami Shahraje, T, Adibnejad, M., Mousavi Koupar, S. A. (2013): Determination of economically optimal rotation age of (Popolus deltoides) in Guilan Province. - Iranian Journal of Forest and Poplar Research 21(1): 6375.

[22] Mohammadi Limaei, S., Lohmander, P. (2007): Stumpage prices in the Iranian Caspian forests. - Asian Journal of Plant Sciences 6(7): 1027-1036.

[23] Mohammadi Limaei, S., Namdari, S., Bonyad, A. E., Naghdi, R. (2011): Economically optimal cutting cycle in a beech forest, Iranian Caspian Forests. - Caspian journal of environmental sciences 9(2): 181-188.

[24] Näslund, B. (1969): Optimal rotation and thinning. - Forest science 15: 446-451.

[25] Newman, D. H. (1988): The optimal forest rotation: a discussion andannotated bibliography. - USDA Forest Service, SoutheasternForest Experiment Station, General Technical Report SE-48, p55. 
[26] Nouri, R. (1999): Study on the possibility of using softwood Kraft pulp from Mazandaran plantation forest (Pinus brutia \& Picea excelsa) instead of imported longfiber pulp for producing different grades of paper in Mazandaran wood and paper industry. - M.sc Thesis, Tarbiat Modaress University, 120p.

[27] Ostakh, E. (2013): Effect of drought stress on tree rings growth and decline of plantation conifers using chronology knowledge (Case study: IRIB Pinus brutia trees in Khorramabad, Iran). - M.sc Thesis, 85pp.

[28] Pasalodos, T. (2010): Optimising forest stand management in Galicia, north-western Spain. - Dissertationes Forestales 102. 52p.

[29] Pearse, P. H. (1967): The optimum forestry rotation. - Forestry Chronicle 43: 178-195.

[30] Petit, B., Montagnini, F. (2004): Growth equations and rotation ages of ten native tree species in mixed and pure plantations in the humid neotropics. - Forest Ecology and Management 199: 243-257.

[31] Posavec, S., Beljan, K., Krajter, S., Peršun, D. (2011): Calculation of Economic Rotation Period for Even-Aged Stand in Croatia. - SEEFOR 2(2): 109-113.

[32] Pourmajidian, M. R., Kalantari, H., Darabi, S., Haidari, M. (2013): Determining appropriate poplar clone and rotation length economically, Advances in Environmental Biology Advances in Environmental Biology 7(10): 3160-3162.

[33] Radaei, O. (2002): Qualitative and quantitative study of the region and the success of Hassan Abad Branch Brutia pine. - M.sc Thesis, Gorgan University of Agricultural Sciences and Natural Resources, Faculty of Forestry 102 p.

[34] Ranjbar, R., Darabi, S., Kalantari, H. (2009): Determine the most suitable clones and optimal period lenght based on economic principles. - Iranian Community forestry, Third National Conference of Forest.

[35] Reed, W. J. (1986): Optimal harvesting models in forest management -a survey. - Natural Resource Modeling 1(1): 55-79.

[36] Sadegh Zadeh Hallaj, M. H., Rostaghi, A. A. (2011): Study on growth performance of Turkish pine (Case study: Arabdagh afforestation plan, Golestan province). - Iranian Journal of Forest 3(3): 201-212.

[37] Sardabi, H. (1998): The various species of eucalyptus and pine compatibility in coastal and low-lying East of Mazandaran. - Forests and rangelands Research Institute 193: 133 $\mathrm{pp}$.

[38] Üner, B., Karaman, İ., Tanrıverdi, H., Özdemir, D. (2011): Determination of lignin and extractive content of Turkish Pine (Pinus brutia Ten.) trees using near infrared spectroscopy and multivariate calibration. - Wood Science and Technology 45: 121- 134.

[39] Usta, H. (1991): A study on the yield of Pinus brutia ten Plantations. - Turkish Forest Research Institute. Technical Bulletin 219: 118-138.

[40] Yousefi, M., Pourmajidian, R. M., Karimia, M., Darvishi, L. (2013): Quantitative and qualitative evaluation of forest plantations by four species and suggestion the appropriate species in the Hyrcanian forest. - European Journal of Experimental Biology 3(5):352360 .

[41] Zhang, D. (2001): Faustmann in an uncertain policy environment. - Forest Policy and Economics 2: 203-210.

[42] Zobeiry, M. (1994): Forest inventory (Measurment of tree and forest). - Tehran University Press NO. 3, 401 pp. 